\title{
The current state and prospects for hydrogenisation of motor transport in Northwestern Europe and Poland
}

ARTICLE INFO

Received: 18 September 2021

Revised: 5 October 2021

Accepted: 5 December 2021

Available online: 16 December 2021
The article presents the situation regarding the hydrogenisation of motor transport in Northwestern Europe, a region leading in this regard in Europe. The following countries were included in the analysis of national plans in this area, taking into account both technical issues - among others - concerning HRS and FCEV, their number, as well as economic issues (among other things relating to the costs of using hydrogen): Belgium, Denmark, France, Germany, the Netherlands, Norway and England. Reference was also made to the situation in Poland, where major fuel and energy companies (among others: Orlen, Lotos, PGNiG and ZE PAK Capital Group) are strongly interested in hydrogenisation of motor transport and manufacturers of vehicles - for example - Solaris or Autosan in producing vehicles equipped with fuel cells. Based on the analyses carried out at the Institute of Motor Transport, it was found that the good location of basic hydrogen refuelling stations is along the TEN-T corridors running across Poland. The order of their location is as follows: 1 - Poznan, 2 Warsaw,3-Bialystok, 4-Szczecin, 5- Łódź region, 6-Tricity, 7-Wroclaw, 8-Katowice region, 9 -Kraków.

Key words: motor transport, hydrogen, fuel cell

This is an open access article under the CC BY license (http://creativecommons.org/licenses/BY/4.0/)

\section{Introduction}

The European Union is the first in the world to introduce a restrictive law prohibiting the registration of new passenger cars equipped with internal combustion engines from 2035. This is the result of the adopted package of solutions [1], which sets out a reduction in greenhouse gas emissions by at least $55 \%$ by 2030 compared to the level of 1990 [2]. In 2050, the European Union is to become the first net zero-emission region in the world. At the same time, the European Union is proposing ambitious targets for reducing carbon dioxide emissions from new passenger cars and trucks: a 55\% reduction in emissions from passenger cars by 2030 and a $50 \%$ reduction in emissions from trucks by 2030 [3].

In addition to the electrification of transport, which is still considered crucial, the simultaneous development of other zero-emission technologies is allowed. Among them is the hydrogenisation of transport. Hydrogen is the fuel of the future, the resources of which are practically inexhaustible. It is the most common chemical element in the universe and is one of the most common elements on Earth (mainly in the form of water and organic compounds). Thus, its use may constitute the future of many sectors of the economy, including transport.

The European Union also recognises the potential of hydrogen. In July 2020, the European Commission announced "A hydrogen strategy for a climate - neutral Europe" [4]. This is a strategic vision for the implementation in 2050 of "The European Green Deal" (European climate neutrality in 2050) [5-8].

In the wake of the COVID-19 pandemic, the European Union has decided to adopt an ambitious economic recovery plan. It has allocated EUR 750 billion for this purpose, including EUR 500 billion for grants and EUR 250 billion for loans to the Member States [6].
In the document mentioned above [6], the reconstruction process is divided into pillars. The first concerns support for the Member States for investment and reforms. The second pillar is kick-starting the EU economy by incentivising private investment. The third pillar is learning the lessons of the crisis. This is directly related to the cooperation of - among others - public authorities, industry and civil society - e.g. within the framework of the European Clean Hydrogen Alliance, based on the European Battery Alliance.

A gradual implementation of hydrogen has been announced. In the first phase, in 2020-2024, there are plans to install at least $6 \mathrm{GW}$ of renewable hydrogen electrolysers in the EU (production of up to 1 million tonnes of renewable hydrogen). In the second phase (2025-2030), hydrogen will become an integral energy carrier in an integrated energy system in which at least $40 \mathrm{GW}$ of renewable hydrogen electrolysers will have been installed by 2030 (production of 10 million tonnes of renewable hydrogen in the EU). In the third phase (2030-2050), technologies for effective decarbonisation will be used on a large scale $[4,9]$.

The potential in the hydrogen technology is recognized by Western European countries, including North-western European such as: Belgium, Denmark France, Germany, the Netherlands, Norway, and the United King-dom. Today, this region concentrates around 5\% of global hydrogen demand and $60 \%$ of European demand [10].

According to Baseline scenario developed by International Energy Agency (IEA) - describes how demand for hydrogen could evolve considering energy- and climaterelated policies already in place in the Northwestern European countries - hydrogen demand for transport (heavyduty vehicles (HDV), medium-duty vehicles (MDV) buses, light-commercial vehicles (LCV), passenger light-duty vehicles (PLDV), shipping, rail and aviation) in the region would reach around $300 \mathrm{kt}_{2}$ by 2030 , driven by hydrogen use in fleets, such as buses and trucks, corresponding to 
close to $10 \%$ of the hydrogen demand in Northwestern Europe [10].

Urban transit buses represent a major opportunity. In particular, national targets for fuel cell bus deployment are deemed more feasible relative to PLDV, resulting in stock share of around $10 \%$ in the Netherlands [10].

The Accelerated scenario is based on enacting more ambitious energy- and climate-related policies and implementing supporting mechanisms that could facilitate adoption of hydrogen technologies [10].

In the Accelerated scenario, hydrogen use expands to light-commercial vehicles (LCV) and PLDV as well as shipping (mainly in the form of ammonia), resulting in an overall hydrogen demand of more than $1 \mathrm{Mt} \mathrm{H}_{2}$ by 2030 (around 15\% of the region's overall hydrogen demand). In PLDVs would reach over 1 million vehicles by 2030 and a share of around $1 \%$ of the stock. The stock number of HDVs by 2030 , at 33,000, is much lower, but their typically higher annual mileage boosts hydrogen demand [10].

The realization of the Accelerated scenario would require expanding from the less than $200 \mathrm{HRS}$ currently operating in the region to a range of 3000 to 4400 HRS [10].

In later chapters in case of FCEV (passenger cars and vans) mostly were passenger cars, whereas FCV mostly were FCEV.

\section{Hydrogen Refueling Stations (HRS) Worldwide as of the end 2020, including HRS at Northwest Europe}

At the end of 2020, 540 HRSs were in operation, including both public and private installations. Most HRSs are concentrated to Asia (278), followed by Europe (190) and North America (68). The country with the highest number of stations was Japan (137), Germany (90), China (85), the U.S. (63), ahead of South Korea (52) and France (38) [11]. In Northwest Europe (Belgium, Denmark, France, Germany, the Netherlands, Norway, and the United Kingdom) was 158 HRS in total at the end of 2020, it is about $83 \%$ HRS in Europe.

The growth in the number of HRS around the world over the 2017-2020 was as follows: 2017 (330), 2018 (381), 2019 (468), 2020 (540) [11]. The number of FCEVs per HRS in the six countries with the highest number of HRSs as of the end of 2020 was as follows: South Korea 194.1, U.S. 146.9, China 99.3, Japan 30.7, Germany 12.0, France 10.4. Most of the stations for passenger cars are operated at 700 bars, but for buses typically utilize was 350 bars [11]. Deployment status of HRS in Motor Transport as of end 2020 (2021 update) at Northwest Europe against the backdrop of the world is presented in Table 1 [11].

\section{Fuel Cell Vehicles (all vehicle types) as of end 2020 (also in the case of Northwest Europe Countries)}

An analysis indicates that 34,804 Fuel Cell Vehicles (FCV) of all types were in operation worldwide as of the end of 2020 (cars and vans; buses-with more than eight seats in addition to the driver's seat; light commercial vehicles-with a maximum mass not exceeding 3.5 tonnes; medium duty-trucks with a maximum mass exceeding 3.5 tonnes but not exceeding 12 tonnes; heavy duty trucks with a maximum mass exceeding 12 tonnes) [11]; (Table 2).

Table 1. Deployment status of HRS in Motor Transport as of the end 2020 at Northwest Europe against the backdrop of the world [11]

\begin{tabular}{|c|c|c|}
\hline Country & $\begin{array}{c}\text { Number of HRSs } \\
\text { (public stations) }\end{array}$ & Notes \\
\hline Asia & 278 & - \\
\hline Japan & 137(137) & 700 bar \\
\hline China & $85(66)$ & - \\
\hline South Korea & $52(-)$ & - \\
\hline India & $2(-)$ & 350 bar \\
\hline Malaysia & $1(-)$ & dual-350/700 bar \\
\hline Taiwan & $1(-)$ & - \\
\hline Australia & 1(1) & 350 bar \\
\hline Europe & 190 & - \\
\hline Germany* & $90(90)$ & $\begin{array}{l}700 \text { bar ( } 7 \text { dual - } \\
350 / 700 \text { bar) }\end{array}$ \\
\hline France* & $38(28)$ & 350-700 bar \\
\hline U.K.* & 13(10) & $\begin{array}{c}2 \times 350 \text { bar, } \\
11 \times 350 / 700 \text { bar }\end{array}$ \\
\hline Austria & $7(5)$ & $\begin{array}{c}\text { both } 350 / 700 \text { bar } \\
\text { available }\end{array}$ \\
\hline Switzerland & $6(-)$ & - \\
\hline Denmark* & $6(6)$ & - \\
\hline Italy & $5(1)$ & $\begin{array}{c}\text { both } 350 / 700 \text { bar } \\
\text { available }\end{array}$ \\
\hline Spain & $5(2)$ & $4 \times 350,1 \times 700$ bar \\
\hline Sweden & $5(5)$ & $\begin{array}{l}\text { mainly } 700 \mathrm{bar}, 2 \\
\text { dual }(350 / 700 \mathrm{bar})^{1 /}\end{array}$ \\
\hline Netherlands* & $5(3)$ & $\begin{array}{l}3 \text { dual } 350 / 700 \text { bar, } \\
1 / 2-350 \text { bar }\end{array}$ \\
\hline Belgium* & 3(2) & $\begin{array}{l}1 \text { dual 350/700 bar, } \\
1-350 \text { bar, 1-700 bar }\end{array}$ \\
\hline Norway* & 3(-) & 2-700 bar, 1-350 bar \\
\hline Croatia & $1(1)$ & 1-30 bar (bicycles) \\
\hline Czech Republic & $1(1)$ & 350 bar \\
\hline Latvia & $1(1)$ & 350 bar \\
\hline Iceland & $1(-)$ & 750 bar \\
\hline North America & 68 & \\
\hline U.S. & $63(46)$ & $350 \mathrm{bar}$ and $700 \mathrm{bar}$ \\
\hline Canada & $5(3)$ & 700 bar \\
\hline Central America & 1 & \\
\hline Costa Rica & $1(-)$ & 350 bar \\
\hline Middle East & 2 & \\
\hline Saudi Arabia & $1(-)$ & 700 bar \\
\hline United Arab Emirates & $1(-)$ & 700 bar \\
\hline Worldwide & 540 & - \\
\hline
\end{tabular}

The vehicle mix is as follows: passenger cars (74.5\%), buses $(16.2 \%)$, and medium-duty trucks $(9.1 \%)$, light commercial vehicles plus heavy-duty trucks $(0.2 \%)$. Most passenger cars are in Asia (55\%), followed by North America $(36 \%)$ and Europe (9\%). In the U.S. more than $99 \%$ fuel cell vehicle fleet is composed of passenger cars [11]; Table 2.

In Northwest Europe Countries fuel cell passenger cars and vans had at the end 2020 the following part in fleets of hydrogen vehicles: Germany 93.8\%, France $94.7 \%$, U.K. $87 \%$, Denmark 97.5\%, Netherlands 91.8\%, Belgium 91.4\%, Norway $97.0 \%$. In total, these vehicles had $89.8 \%$ participation in FCV in Europe as of the end of 2020 (Table 2). 
Table 2. Number of Fuel Cell Vehicles in Motor Transport as of the end 2020 at Northwest Europe against the backdrop of the world [11]

\begin{tabular}{|c|c|c|c|c|c|c|}
\hline \multirow[t]{2}{*}{ Country } & \multirow{2}{*}{ 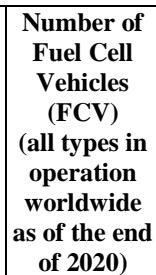 } & \multicolumn{5}{|c|}{$\begin{array}{c}\text { Notes } \\
\text { Number of }{ }^{1 /}\end{array}$} \\
\hline & & \begin{tabular}{|c|} 
Pass. \\
cars and \\
vans \\
$($ FCEV $)$
\end{tabular} & $\begin{array}{l}\text { Buses } \\
\text { (FCB) }\end{array}$ & LCV & MDT & HDT \\
\hline Asia & \begin{tabular}{|l|}
22746 \\
$(65 \%)$ \\
\end{tabular} & $\begin{array}{l}14141 \\
(55 \%) \\
\end{array}$ & $\begin{array}{c}\mathbf{5 4 5 2} \\
(\mathbf{9 7 \%}) \\
\end{array}$ & - & - & - \\
\hline \begin{tabular}{|l|} 
Japan \\
\end{tabular} & 4200 & 4100 & - & - & - & - \\
\hline China & 8443 & - & $\begin{array}{c}5290 \\
\text { (93.7\% of } \\
\text { the } \\
\text { worldwide } \\
\text { FCB fleet) }\end{array}$ & - & $\begin{array}{c}3153 \\
\text { (99.7\% } \\
\text { of the } \\
\text { world- } \\
\text { wide } \\
\text { MDT } \\
\text { fleet) }\end{array}$ & $\begin{array}{c}(50 \\
\text { were } \\
\text { produced } \\
\text { but had no } \\
\text { registered } \\
\text { by the end } \\
\text { of 2020) }\end{array}$ \\
\hline \begin{tabular}{|l|} 
South \\
Korea \\
\end{tabular} & 10093 & 10041 & - & - & - & - \\
\hline India & 10 & - & - & - & - & - \\
\hline Malaysia & - & - & - & - & - & - \\
\hline Taiwan & - & - & - & - & - & - \\
\hline Australia & 6 & - & - & - & - & - \\
\hline \begin{tabular}{|l|} 
Europe \\
\end{tabular} & $2667(8 \%)$ & $\begin{array}{l}2465 \\
(9 \%)\end{array}$ & $\begin{array}{c}131 \\
(2 \%)\end{array}$ & - & - & - \\
\hline Germany* & 1083 & 1016 & - & - & - & - \\
\hline France* & 396 & 375 & - & - & - & - \\
\hline U.K. * & 193 & 168 & - & - & - & - \\
\hline Austria & 47 & 45 & - & - & - & - \\
\hline Switzerland & 115 & 93 & - & - & - & - \\
\hline Denmark* & 120 & 117 & - & - & - & - \\
\hline Italy & 34 & 22 & - & - & - & - \\
\hline Spain & 17 & 17 & - & - & - & - \\
\hline \begin{tabular}{|l|} 
Sweden \\
\end{tabular} & 51 & 50 & - & - & - & - \\
\hline $\begin{array}{l}\text { Nether- } \\
\text { lands* }\end{array}$ & 342 & 314 & - & - & - & - \\
\hline Belgium* & 70 & 64 & - & - & - & - \\
\hline Norway* & 164 & 159 & - & - & - & - \\
\hline Croatia & - & - & - & - & - & - \\
\hline $\begin{array}{c}\text { Czech } \\
\text { Republic }\end{array}$ & 1 & 1 & - & - & - & - \\
\hline \begin{tabular}{|l} 
Latvia \\
\end{tabular} & 10 & - & - & - & - & - \\
\hline \begin{tabular}{|l|} 
Luxemburg \\
\end{tabular} & 2 & 2 & - & - & - & - \\
\hline \begin{tabular}{|l|} 
Iceland \\
\end{tabular} & 22 & 22 & - & - & - & - \\
\hline \begin{tabular}{|l|} 
North \\
America
\end{tabular} & $9380(27 \%)$ & $\begin{array}{c}9316 \\
(36 \%)\end{array}$ & $\begin{array}{c}64 \\
(1 \%)\end{array}$ & - & - & - \\
\hline \begin{tabular}{|l|} 
U.S. \\
\end{tabular} & 9252 & 9188 & - & - & - & - \\
\hline \begin{tabular}{|l|} 
Canada \\
\end{tabular} & 128 & 128 & - & - & - & - \\
\hline $\begin{array}{l}\text { South } \\
\text { America }\end{array}$ & 1 & 1 & - & - & - & - \\
\hline Brazil & 1 & - & - & - & - & - \\
\hline \begin{tabular}{|l|} 
Central \\
America \\
\end{tabular} & 4 & 4 & - & - & - & - \\
\hline \begin{tabular}{|l|} 
Costa Rica \\
\end{tabular} & 4 & - & - & - & - & - \\
\hline Middle East & - & - & - & - & - & - \\
\hline \begin{tabular}{|c|} 
Saudi \\
Arabia \\
\end{tabular} & - & - & - & - & - & - \\
\hline \begin{tabular}{|c|} 
United Arab \\
Emirates
\end{tabular} & - & - & - & - & - & - \\
\hline Worldwide & $\begin{array}{c}34804 \\
(100 \%)\end{array}$ & $\begin{array}{l}2^{25932}{ }^{2 /} \\
(100 \%)\end{array}$ & $5648^{3 /}$ & 49 & 3161 & 14 \\
\hline $\begin{array}{l}* \text { Northwest } \\
\text { MDT }-\mathrm{Mec} \\
\text { the rest of th } \\
\text { Fuel Cell Bu }\end{array}$ & $\begin{array}{l}\text { Europe coun } \\
\text { dium-Duty Tr } \\
\text { he world ( } 5 \text { pa } \\
\text { us }- \text { FCB) }\end{array}$ & $\begin{array}{l}\text { acks; HD } \\
\text { ass. cars); }\end{array}$ & $\begin{array}{l}\text { CV - Light } \\
\text { V - Heavy } \\
\text { 3/ including }\end{array}$ & $\begin{array}{l}\text { Comr } \\
\text { Duty } \\
\text { g the r }\end{array}$ & $\begin{array}{l}\text { ercial Ve } \\
\text { rucks; } 2 / \\
\text { st of the }\end{array}$ & $\begin{array}{l}\text { hicles; } \\
\text { including } \\
\text { world (1 - }\end{array}$ \\
\hline
\end{tabular}

\section{Motor transport hydrogenization in North- Western Europe courtiers}

\section{Belgium}

Within the framework of the European HIT-2-Corridors project in December 2015 a proposal was developed - Na- tional Implementation Plan - Hydrogen Refuelling Infrastructure Belgium $[9,12,13]$. According to the said proposal, taking into account the average percentage of HRS stations in 2015-2020, 2020-2025, 2025-2030 in the total number of petrol stations in those years in respective countries, among others such as Germany, the UK, the Netherlands, France, Denmark, it was estimated in the said proposal that in the case of Belgium with about 3.200 petrol stations, the amount of HRS refers to $0.8 \%$ (2020) via $2.3 \%$ (2025) to $4.7 \%$ (2030). This is completely in line with the targets in other H2-Mobility countries. Thus, in years:

- 2015-2020 there should be 25 HRSs (20 in Flanders and 5 in Walloon region),

- 2020-2025 there should be 75 HRSs (50 in Flanders and 20 in Walloon region and 5 in Brussels),

- 2025-2030 there should be 150 HRSs (100 in Flanders and 40 in Walloon region and 10 in Brussels [9, 12,13].

This results in overall CAPEX for HRS up to 2030 of about 170 million euros. For 2020 should be about 1000 FCEV in Belgium which is almost $0.02 \%$ of the total vehicle fleet. After 2020, during the early market introduction (2020-2025), the amount of FCEV's will grow to possibly 7500 FCEV's. This is almost $0.15 \%$ of the market. Finally, between 2025-2030, a ramp up could emerge which results in 30,000 FCEV ( $0.55 \%$ market penetration). For buses, the target is 50 buses in 2020, 250 in 2025 and 500 in 2030 [14, 15]. At the end of 2017 in Belgium there were, however, for example only 3 HRS (in Antwerp, Halle and Zaventem) and 21 FCEVs and several hydrogen buses $[9,16,17]$.

According to European Alternative Fuel Observatory (EAFO) in Belgium were 2 refuelling points (HRS) and 64 FCEV at the end of 2020 [16]. In the case of the data from Forschungszentrum Jülich $\mathrm{GmbH}$ were 3 HRS (2 public stations) and 64 FCEV (70 Fuel Cell Vehicles (FCV) at the end of 2020 [11]. Summing up in Belgium:2017 (3 HRS, 21 FCEV); 2020 (3 HRS, 64 FCEV); 2025 (150 HRS, 7500 FCEV); 2028 (30,000 FCEV).

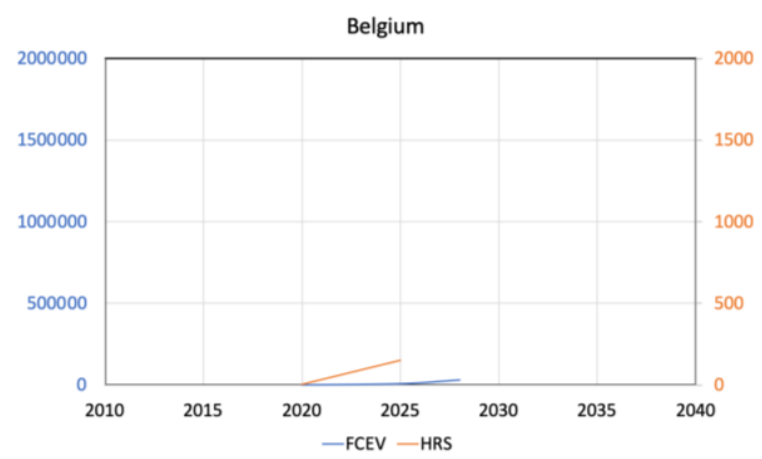

Fig. 1. The number of HRS and FCEVs in Belgium (2017-2028)

\section{Denmark}

The beginnings of the development of hydrogenisation of transport, including automotive transport in Denmark, practically started in 2001 by the creation of the "Danish Hydrogen and Fuel Cell Partnership", in which the Working Group "National FCH Transport Strategy Group" in 2008 prepared a national program "National R\&D and demonstration strategy for FCH Transport". Between 2011 and 2014, several projects were implemented, co-financed 
by FCH-JU (The Fuel Cells and Hydrogen Joint Undertaking). In 2014, the "National Implementation Plan (NIP) for hydrogen refuelling infrastructure" was established. The first activities for FCEVs were undertaken in 2001 and for HRS - in 2006 [9, 19].

In March 2014, 17 FCEVs were in operation, mainly Hyundai iX35 cars and there were 3 HRS operating (in September 2014, the 4th was built). The focus was on supplying passenger cars with hydrogen at a pressure of 70 MPa. It was assumed that in 2025 electrical energy would be used, generated from hydrogen in 4.8 and in 2030 $15.7 \%$ and $50 \%$ in 2050 , replacing that derived from conventional fuels. Total electricity generation from renewable sources was expected in 2050. At the end of 2017, $10 \mathrm{HRSs}$ (85 FCEV and several FCEB) were operated in Denmark [16]. According to EAFO in Denmark were 8 refuelling points (HRS) and $148 \mathrm{FCEV}$ at the end of 2020 [18]. In the case of the data from Forschungszentrum Jülich $\mathrm{GmbH}$ were 6 HRS ( 6 public stations) and 117 FCEV (120 FCV) at the end of $2020[9,11]$.

The development scenarios of the FCEV fleet were made dependent on its dynamics. Thus, in the scenario assuming high development of the FCEV, it was assumed that in 2050 there would be 1.4 million vehicles $(50 \%$ of the passenger car fleet). In the medium-sized development scenario of FCEV in the said year there were to be 1.1 million FCEVs (37.5\% of the passenger car fleet), and 0.7 million FCEV (25\% of the passenger car fleet) in the low development scenario of FCEVs in 2050. Those variants assumed respectively - in the high development scenario for FCEV the use of 100,000 FCEVs in 2015 (4\% of the passenger cars fleet), in the medium-sized development in 2025 operation $-50,000$ FCEVs ( $2 \%$ of the said fleet) and in the low development scenario operation in $2025-25,000$ (1\% of the said fleet) $[9,19]$.

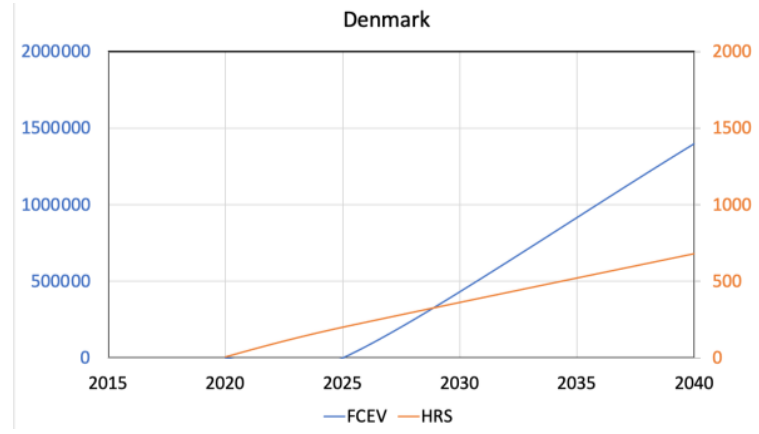

Fig. 2. The number of HRS and FCEVs in Denmark (2017-2050)

Whereas, in 2025, regarding HRS in the scenario assuming high development of FCEVs around $200 \mathrm{HRSs}$ should be operated, roughly $1000 \mathrm{HRSs}$ in 2050 , and in the scenarios of low and medium development, in 2025 - approx. 100 HRSs and in 2050 - 500 HRSs. In Denmark analyses are made of the central, and local production of hydrogen. Electrolyser capacity in 2025, 2035, and 2050 is $88 \mathrm{MW}, 579 \mathrm{MW}$ and $1063 \mathrm{MW}$ respectively, used in $85 \%$ $[9,19]$.
Summing up in Denmark: 2017 (10 HRS, 85 FCEV); 2020 (6 HRS, 117 FCEV); 2025 (100-200 HRS); 2050 (500-1000 HRS, 700,000-1,400,000 FCEV).

\section{France}

A hydrogenisation development plan in France, including motor transport, was prepared by the H2Mobilité France Consortium in 2013 and envisaged significant development of FCEV refuelling infrastructure from $96 \mathrm{HRS}$ in 2022 to 602 HRS in 2030 (in 2026-2030 with a decreasing share of HRS with a hydrogen generation capacity of $212 \mathrm{~kg} / \mathrm{d}$ in favour of HRS with a hydrogen production capacity of $420 \mathrm{~kg} / \mathrm{d}$ ) and the development of FCEVs from 23 thousand in 2022 to 773,000 in 2030, with hydrogen demand of up to 3,000 tonnes in 2022 , to 89,000 tonnes in 2030 and electrical energy demand from $115 \mathrm{GWh}$ p.a. in 2022 to 3,251 GWh p.a. in 2030 [9, 20].

According to the aforementioned development plan, in 2040 and 2050, the fleet of FCEV and light trucks will be 3.7 million vehicles and 7.3 million vehicles respectively, with a share of $9 \%$ and $17 \%$ in the total French market of passenger and light trucks [20]. With regard to reducing $\mathrm{CO}_{2}$ emissions, the introduction of the said fleet of hydrogen vehicles would provide in a life cycle (with an average annual mileage of $15,600 \mathrm{~km}$ and mix hydrogen production $-75 \%$ using electrolysers) of $1.2 \mathrm{tCO}_{2}$ per year by vehicle in 2030 , when the societal cost of $\mathrm{CO}_{2}$ is evaluated at 105 euro per tonne [20]. At the end of 2017, there were 19 hydrogen refuelling stations and 263 vehicles served by them in France [16]. At the end of 2019, there were 26 HRSs operating and 34 planned in France. Most of the French HRS aim at refuelling of buses and delivery vehicle fleets $[9,21]$.

According to EAFO in France were refuelling points 36 (HRS) and 148 FCEV at the end of 2020 [18]. In the case of the data from Forschungszentrum Julich $\mathrm{GmbH}$ were 38 HRS (28 public stations) and 375 FCEV (396 FCV) at the end of 2020 [11]. However, according to International Partnership for Hydrogen and Fuel Cells in Economy (IPHE) were $41 \mathrm{HRS}, 381 \mathrm{FC}$ cars and 22 FC buses (updated July 2021) [22].

In 2018, presented was based on an in-depth "Hydrogen scaling up" study on the use of hydrogen in key areas of the world economy a plan for the development of hydrogenisation in France, including in motor transport [9, 23]. This plan assumes among others that:

- the number of HRS in 2023 will be 140 and 400 in 2028 ,

- the number of passenger cars and light trucks using fuel cells will be 10,000 in France in 2023 and 200,000 vehicles in 2028, and in $205018 \%$ of used passenger vehicles and light trucks will use hydrogen, as well as $25 \%$ of the registered bus fleet and $20 \%$ of the fleet of registered heavy trucks,

- investment expenditure - for example - for the implementation of 600 HRSs comes to 750 million euro.

The hydrogen distribution plan for the energy transition in 2018-2028 was presented by Minister for Ecological Transformation Nicolas Hulot on 01.062018 [9, 24]. According to that plan: 
- in 2023 in France there should be 5000 light trucks, 200 buses and heavy-duty vehicles equipped with hydrogen fuel cells and $100 \mathrm{HRSs}$,

- in 2028 from 20,000 up to 50,000 light trucks, from 800 to 2000 buses and heavy-duty vehicles equipped with hydrogen fuel cells and from 400 to $1000 \mathrm{HRSs}$,

- in $201718.5 \%$ of electricity was derived from renewable sources and $40-60 \%$ of that energy should be stored,

- production of hydrogen by electrolysers is considered very important, for example Michelin plans to implement 15 electrolysers, 20 hydrogen refuelling stations and the purchase of 1000 vehicles equipped with hydrogen fuel cells (Zero Emission Valley project - Auvergne-Rhône-Alpes region),

- roughly 200 light hydrogen Hy-Kangoo trucks by symbioFC are used (price approx. 30 thousand euros). The price of $12 \mathrm{~m}$ of bus is about 450 thousand euro. Hydrogen buses are already in use in French cities.

Summing up in France: 2017 (19 HRS, 263 FCEV); 2019 (26 HRS+34HRS planned); 2020 (38 HRS, 375 FCEV); 2023 (100-140 HRS, 10,000 FCEV); 2028 (4001000 HRS, 200,000 FCEV); 2030 (602 HRS, 773,000 FCEV).

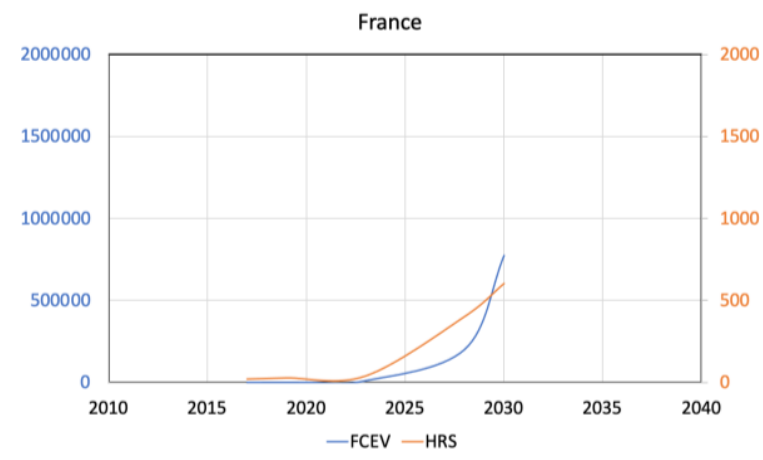

Fig. 3. The number of HRS and FCEVs in France (2017-2030)

\section{Germany}

A broader interest in the hydrogenization of motor transport in the Germany took place at the end of the 1990s. At that time, a several of works were carried out on the energy use of hydrogen in motor transport, its transport or distribution. An example could be the co-operation "Verkehrswirtschaftliche Energiestrategie" (VES, Transport Energy Strategy) between German politics and private companies which was founded in 1998. It was targeted at developing strategies to ensure a global leading role of the German car industry in alternative fuel technologies [9, 23].

Another example can be the CEP (Clean Energy Partnership, established in 2002) emerged from the VES as a joint political initiative, lead-managed by the German Ministry of Transport and Industry. While the VES took a more theoretical approach, the CEP puts the knowledge gained into practice. CEP has three phases: 2002-2008, 2008-2010 and 2011-2016 of different tasks. For instance, the second phase was committed to the qualification of applications in daily usage, e.g., improvement of vehicle efficiency and cold-start abilities as well as a cost reduction in vehicle and infrastructure technologies. In 2014, about 85 FCEV were operated within the framework of the CEP $[9,23]$.

Yet another example can be the H2-Mobility Initiative (2009), which originates from the VES. The Initiative, making it the centrepiece for the commercialization of FCEVs in Europe. The H2-Mobility initiative was transformed to a Joint Venture in 2012/13. The Initiative reviewed various options for building a Germany-wide H2infrastructure assuming the serial production of FCEVs and public co-financing of further HRS and their development, in particular in large agglomerations. In 2012, it was expected that in 2020 there would be around 400 HRSs and approx. 150,000 FCEVs (in 2030 - 1000 HRSs and $1,800,000 \mathrm{FCEVs}$, respectively). It was also assumed that in 2023 there will be 500 HRSs operating, 500,000 FCEVs and 2 thousand FCEBs (Fuel Cell Electric Bus) [9, 23].

In 2012 Daimler, Linde, Air Products, Air Liquide and Total agreed to invest $20 \mathrm{M} €$ in a further 36 stations up to a total of 50 stations with the support of the Federal Government (NIP) by 2015 (due to the delayed market introduction of FCVs. It should be pointed out that the first public compressed hydrogen refuelling station was launched in Hamburg as early as in January 1999 and the world's first public liquid hydrogen station was launched at Munich Airport in May this year [24, 25]. However, at the end of December 2015, only 20 HRSs and 150 FCEVs were used [9, 26].

In the result of the undertaken efforts federal government, federal states, industry and science in 2006 "National Innovation Programme Hydrogen and Fuel Cell Technology" (NIP I) was adopted, functioning in years 2006-2016, which comprised a funding volume of 1.4 billion euros (in studies applied in the area of transport 471 projects were performed and 238 demonstrative projects). A governmental National Organization Hydrogen and Fuel Cell Technology - NOW was established in 2008 to manage the programme. It also operates in the area of electrical mobility. The above projects CEP and H2-Mobility Initiative have been included among others in NIP I. NOW organisation also operates the NIP II government programme for hydrogen and fuel cell technology for the period of 2016-2026. In this second phase, only the Federal Ministry of Transport and Digital Infrastructure (BMVI) was initially investing 250 million euros until 2019 to support hydrogen and fuel cell technology for the implementation of the programme [9, 27].

In the first stage of the development of the hydrogen refuelling infrastructure in the Germany by 2015, planned within the framework of $\mathrm{H} 2$ Mobility Initiative under the auspices of NIP I was the launch of 50 public HRS (vs. even 100 HRSs initially assumed). At the end of 2017, there were however 56 hydrogen refuelling stations in Germany, used by several hundred FCEVs (approx. 300). The construction of the aforesaid 50 HRS was completed in 2018 [28]. In the second phase of the development of this infrastructure by the end of 2020, with an investment of 350 million euro, 100 hydrogen refuelling stations are planned to be launched and by the end of 2023 (initially by the end of 2025) 400 HRSs (10 HRSs each in the 6 largest metropolises, while ensuring a maxi-mum distance of $90 \mathrm{~km}$ between 
HRS on motorways. In 2030 there should be 1000 HRS with full commercialisation [9, 29-32].

The main objective of the use of hydrogen in Germany in the case of motor transport is to reduce greenhouse gas emissions (mainly $\mathrm{CO}_{2}$ ) and energy consumption by the said transport and to increase the share of renewable energy. The targets are as follows: a $40 \%$ reduction in greenhouse gas emissions in 2020 and 80-95\% in 2050 vs 1990 for greenhouse gas emissions, and respectively a reduction by $10 \%$ and $40 \%$ in final energy consumption vs 2008 , with an increase in the use of renewable energy up to - respectively $-18 \%$ and $60 \%$ in final energy consumption [32]. This involves the production of hydrogen based on electrolysers, the power of which is likely to be greater than 10 GW in $2030[9,33]$.

FCEVs currently have a long range of 400-700 km with a single refuelling, with refuelling time similar to that of conventional passenger cars, and investments in the refuelling infrastructure at 20 million FCEVs are equal to $€ 40$ billion ( $€ 51$ billion for BEV - Battery Electric Vehicle), which gives FCEV an advantage over BEV [34,35]. In Germany, there were 87 hydrogen refuelling stations at the end of 2019 [36]. According to EAFO in Germany were 88 refuelling points (HRS) and $738 \mathrm{FCEV}$ at the end of 2020 [18]. In the case of the data from Forschungszentrum Julich GmbH were $90 \mathrm{HRS}$ (90 public stations) and 1016 FCEV (1083 FCV) at the end of 2020 [11]. However, according to IPHE were 97 HRS, 1195 FC cars, 79 FC buses and 2FC Trucks (updated July 2021) [22].

Summing up in Germany: 2015 (20 HRS, 150 FCEV); 2017 (56 HRS, 300 FCEV); 2019 (87 HRS); 2020 (90 HRS, 1016 FCEV); 2023 (400 HRS); 2030 (1000 HRS, 1,800,000 FCEV).

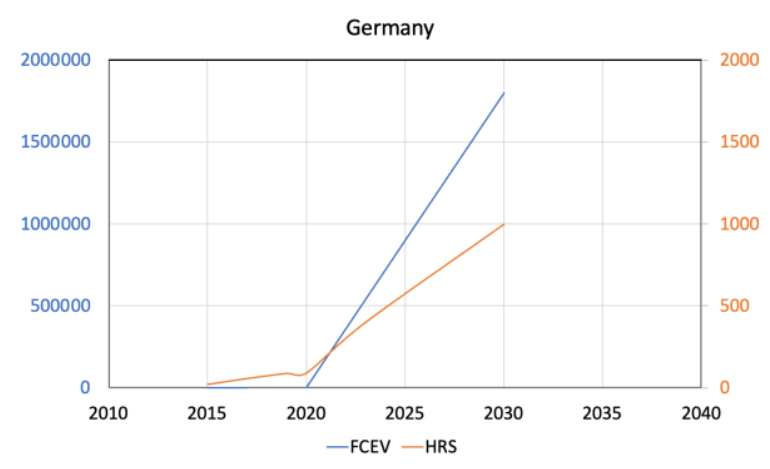

Fig. 4. The number of HRS and FCEVs in Germany (2015-2030)

\section{The Netherlands}

The Ministry of Infrastructure and Environment of the Netherlands at the end of 2011 initiated works on a programme on the hydrogenization of transport, and the resulting conclusions were presented in 2013. The program consisted of four phases:

- Phase 0 (2000-2012; research and development),

- Phase 1 (2012-2015; market preparation),

- Phase 2 (2015-2020; market introduction and yet market preparation),

- Phase 3 (after 2020; mass production and yet market preparation).
This programmed was concretized in the EU project The Hydrogen Infrastructures for Transport (HIT), where 4 phases were also adopted. These were: Phase 1 (20142017; market preparation, 2-20 HRS, 1,500 hydrogen vehicles, access by $20 \%$ of the population), Phase 2 (20182023; early market introduction, 20-50 HRSs, 1500-15,000 hydrogen vehicles, access by $50 \%$ of the population), Phase 3 (2024-2030; full market introduction, 50-200 HRSs, $15,000-125,000$ hydro- gen vehicles, access by $90 \%$ of the population), Phase 4 (after 2030; mass market, 1000-1400 HRSs, > 2.5 million hydrogen vehicles, access by $100 \%$ of the population). Development of the HRS network: initial network of $20 \mathrm{HRSs}$ with $210 \mathrm{~kg}$ /day stations, upgrade of initial stations to $420 \mathrm{~kg}$ /day 5 years after installation, and installation additional $420 \mathrm{~kg} /$ day base on need for HRS capacity resulting from hydrogen demand and network utilization $[9,37,38]$.

At the end of 2017 in the Netherlands functioning were only 3 hydrogen refueling stations and 34 hydrogen vehicles and several buses [16].

According to Dutch H2Platform (May 2018):

- by 2020 there should be: 20 HRS, 2000 FCEVs, 100 FCEBs, 500 vans, 20 trucks,

- whereas in 2030 there should be 216 HRSs, according to: Scenario Low 132,000 hydrogen vehicles, Scenario Mid 375000 hydrogen vehicles, Scenario High 696000 hydrogen vehicles, 300,000 FCEV, 65,000 LCVs (Light Commercial Vehicle), 7700 trucks and 1700 buses. Governmental Subsidies end 2026, total Capital expenditures (Capex) 2018-2030 = C725 million [9, 39, 40].

In July 2017, the Ministry of Economic Affairs and Climate Policy asked TKI Gas (gas network organization in the Netherlands) to manage the process to define the outlines of a roadmap for hydrogen [39]. The report was based on - among others - the findings of the "Hydrogen scalingup" study, referring to the same areas of energy transition as those cited in this study, and assumed was a reduction in greenhouse gas emissions by 80-95\% in 2050 vs 1990 [48]. The report addressed a wide range of issues related to its use. Attention was drawn to the need to develop ways of producing it based on renewable energy, distribution (refueling infrastructure) or use in heavy-duty vehicles [9, 41, 42].

This year a governmental document "Government Strategy on Hydrogen" has been published, stating that the National Climate Agreement includes an ambition to scale up electrolysis to approximately $500 \mathrm{MW}$ of in-stalled capacity by 2025 and 3-4 GW of installed capacity by 2030 . However, in order to support the targets, set out in the National Climate Agreement (50 HRS, 15,000 hydrogen vehicles and 3000 heavy-duty hydrogen vehicles by 2025;300,000 hydrogen vehicles by 2030), a cooperation agreement with various stakeholders will be signed in this year. Electricity will be obtained for electrolysis from offshore wind farms and the gas network will also be used for hydrogen transmission [9, 43].

According to EAFO in Netherlands were $X$ refueling points (HRS) and X FCEVs at the end of 2020 [18]. In the case of the data from Forschungszentrum Jülich $\mathrm{GmbH}$ were 5 HRS ( 3 public stations) and 314 FCEV (342 FCV) 
at the end of 2020 [11]. However, according to IPHE were 7 HRS, 390 FC cars, 12 FC buses and 11 FC Trucks (updated July 2021) [22].

Summing up in Netherland: 2017 (3 HRS, 34 FCEV); 2020 (5 HRS, 314 FCEV); 2025 (50 HRS, 15,000 FCEV); 2030 (216-1000 HRS, 300,000 FCEV).

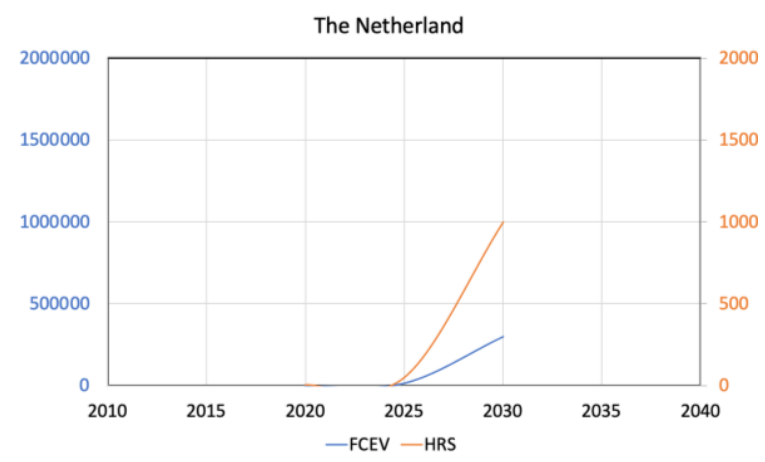

Fig. 5. The number of HRS and FCEVs in the Netherlands (2017-2030)

\section{Norway}

Norwegian greenhouse gas emissions were 52 million tonnes of $\mathrm{CO}_{2}$ equivalents in 2018. Road traffic is responsible for 16.5 million tonnes $\mathrm{CO}_{2}$ equivalents and $32 \%$ of total emissions. Hydrogen and other hydrogen-based systems have the potential to reduce emissions in the transport sector [44].

The Norwegian Hydrogen Council published in 2006 and 2012 two Actions Plans for the periods 2007-2010 and 2012-2015 respectively, plans in aspect use hydrogen. The Council's recommendations were not similarly embraced by the Government (the first National Norwegian Hydrogen Strategy in 2005) [45].

The HyNor-project (nationally supported project) started out as a hydrogen highway-project in Norway. It was initiated by large industrial companies such as Statoil and Norsk Hydro in 2003 with the goal of a market-realistic demonstration of hydrogen refuelling stations, as well as hydrogen vehicles. Several hydrogen refuelling stations were built along the 580-kilometer route from Oslo to Stavanger. Norway's first hydrogen fuelling station was opened in 2006 near Stavanger, the second in Porsgrunn in 2007, and two stations were opened in Oslo and Lier in 2009 [46].

The HyNor-project has tested several different hydrogen vehicles:

- 15 retrofitted Toyota Prius hydrogen internal combustion engine (ICE) vehicles (2007-2012)

- 4 Mazda RX-8 Hydrogen RE dual fuel hydrogen/gasoline ICE vehicles (2009-2012)

- 10 Mercedes-Benz B-class F-CELL (2011-2014)

- 5 Think City hydrogen cars

- 2 Hyundai ix35 FCEVs [46].

All new passenger cars and light vans sold in 2025 shall be zero-emission vehicles, and also new urban buses sold in 2025 shall be zero emitters or use biogas. By 2030, all new heavy-duty vehicles, $75 \%$ of new long- distance coaches and $50 \%$ of new trucks shall be zero emission vehicles [47].

At the end of 2017, were operational in Norway 9 HRS and 94 FCEV [16]. According to IPHE in March 2019, were only 6 HRS, 159 Fuel Cell Vehicles (includes Fuel
Cell electric Vehicles with Range Extenders) and 5 Fuel Cell Buses [22]. By the end of 2019, 149 hydrogen cars, 1 light van, 5 hydrogen buses and 1 hydrogen truck had been registered in Norway. By comparison 260,581 electric cars, 7331 electric vans, 199 electric buses and 21 electric trucks had been registered by the end of 2019 [44]. According to EAFO in Norway were 3 refuelling points (HRS) and 195 FCEV at the end of 2020 [18]. In the case of data from Forschungszentrum Jülich $\mathrm{GmbH}$ were $3 \mathrm{HRS}$ and 159 FCEV (164 FCV) at the end of 2020 [11]. Current status according to IPHE (updated July 2021): 6 HRS, 154 Fuel Cell Cars, 5 FC Buses and 4 Fuel Cell Trucks [22].

Current HRS network in Norway:

- Pursuing - H2 byproduct from chlorine production, 700 bar refueling

- Drammen - Trucked-in hydrogen, 700 bar refueling (shutdown in 2015 and moved to Oslo airport Gardermoen)

- Oslo - Trucked-in hydrogen, 700 bar refuelling

- Oslo - Gaustad - On-site electrolysis (10 Nm³/h), 700 bar refuelling

- Oslo - Rosenholm - On-site electrolysis $\left(2 \times 60 \mathrm{Nm}^{3} / \mathrm{h}\right)$, 350 bar refueling (bus-only station)

- Lillestrom - H2 from biogas via Sorption Enhanced Steam Methane Reforming (SE-SMR) and solar electrolysis, 700 bar refuelling [46].

A study performed by LBST (Ludwig Bölkow Systemtechnik) for Statoil, analysing infrastructure build-up in the greater Oslo area indicates that in: "low scenario" 22,000 cars, "base scenario" 55,000 cars, and "high scenario" 110,000 cars will be in 2025 , and also 30 HRS are to be built until 2025 [48].

In the fall of 2009, a Memorandum of Understanding (MoU) was signed by nine of the leading car manufacturers confirming that they will be ready to introduce hydrogen powered FCEV in the market from 2015. The Norwegian Klimakur2020 has based on this MoU created a scenario where the FCEV are introduced in Norway on a limited scale from 2016 [45]. In 2020 the market share is estimated at 1.5$2 \%$, rising to $12 \%$ in 2030 with a total of 6500 and 124000 FCEVs in the fleet in 2020 and 2030 respectively [49].

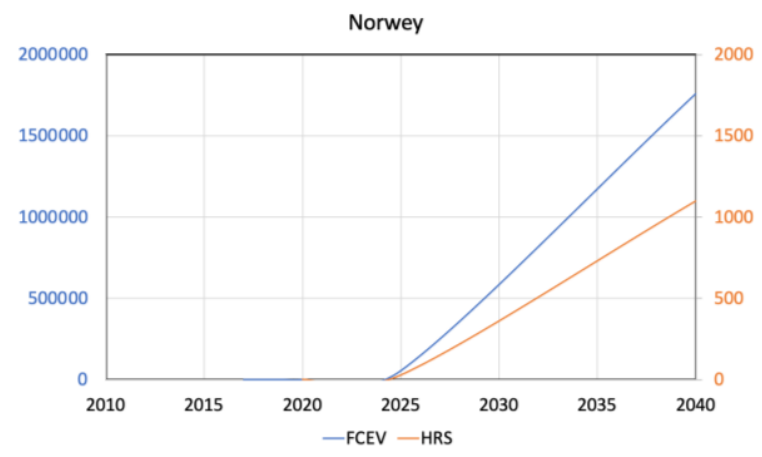

Fig. 6. The number of HRS and FCEVs in Norway (2017-2040)

The Norways study [50] conducted by NTNU (Norwegian University of Science and Technology, located in Trondheim), IFE (Institute for Energy Technology) and SINTEF (largest independent contract research organization in Scandinavia) in 2009, analyses hydrogen production, 
distribution and refuelling in Norway until 2050. The study concludes that complete national coverage of HRS is deemed attainable by 2040 . Hydrogen would be available at 1100 of today's refuelling stations, each serving an average of 1600 vehicles, supplying hydrogen to a total of $1,760,000$ vehicle [48].

Summing up in Norway: 2017 (9 HRS, 94 FCEV); 2019 (6 HRS, 149 FCEV); 2020 (3 HRS, 159 FCEV); 2025 (30 HRS, 55000 FCEV; 2040 (1100 HRS, 1,760,000 FCEV).

\section{United Kingdom}

Within the UK H2 Mobility project determined that an initial minimum network of 65 HRS in 2015 in the right locations represents a good balance between consumer benefit and investment return. This network would cover major population centers, and connecting motorways, and roads to enable national mobility. It is based on having a minimum of two HRS per Local Authority District (LAD) in the targeted regions, with $8 \mathrm{~km}$ between HRS and within, a 10 minute drive. By 2025, 330 HRS was planned. In 2015-2020 in the UK H2 Mobility scenario amounting to 13,000 vehicles in the first five years, was limited by the cost of buying the vehicles. No subsidy for FCEV purchase or operation has been assumed in the roadmap [51].

At the end of 2017 in UK functioning were only 93 FC vehicles [16]. According to EAFO in UK were 12 refuelling points (HRS) $228 \mathrm{FCEV}$ at the end of 2020 [18]. In the case of the data from Forsschungszentrum Jülich $\mathrm{GmbH}$ were 13 HRS (10 public stations) and 168 FCEV (193 FCV) at the end of 2020 [11]. According to IPHE were about 100 FCEV including FCEV with Range Extenders as of Dec. 2018 and 20 FC buses and 13 publically accessible HRS includes both 350 and 700 bar sites. Current status: 168 FC Cars and 1 FC Trucks (updated July 2021) [22].

In 2020, approximately 1000 fuel cell cars and > 30 HRS were expected to be operated in the UK. The expected status in 2025 is > 30,000 FC vehicles (practically, rather 10,000 s of affordable FC vehicles on UK roads), > 150 HRS and 10's of OEM (Original Equipment Manufacturer) FCEV models available [52].

The UK H2 Mobility roadmap shows that by 2030 :

- FCEVs will be at least cost-competitive with conventional vehicles.

- A network of 1,150 HRS can cover the whole country.

- 1.6 million FCEVs could be on UK roads. The HRS network is past its break-even point.

- Hydrogen production and retailing can be an attractive and profitable business leading to the natural growth of the HRS network as the FCEV fleet grows.

- $\mathrm{CO}_{2}$ emissions (including fuel production) can be $75 \%$ lower for FCEVs than for equivalent diesel vehicles,

- and on a trajectory to zero $\mathrm{CO}_{2}$ emissions by 2050 .

- FCEVs will be on course to reach a 20-50\% market share, in line with the Department of Energy and Climate

- Change (DECC) 2050 Pathway Analysis [51].

Hydrogen in United Kingdom is likely to be fundamental to achieving net zero in transport, potentially complementing electrification across modes of transport such as buses, trains and heavy goods vehicles (HGVs).
Transport is also a crucial early market for hydrogen, driving some of the earliest low carbon production in the UK. There are over 300 hydrogen vehicles on UK roads, mostly passenger cars and buses, and the government is supporting hydrogen use in transport with a $£ 23$ million Hydrogen for Transport Programme [53].

Approximately two per cent of England's local operator bus fleet is now zero emission - equipped with battery electric or hydrogen fuel cell. Will be implemented the National Bus Strategy and its vision of a green bus revolution, including setting an end date for the sale of new diesel buses and the Zero Emission Bus Regional Areas (ZEBRA) scheme. ZEBRA will provide up to $£ 120$ million in $2021 / 22$ to begin delivery of 4,000 new zero emission buses, either hydrogen or battery electric, and the infrastructure needed to support them [53].

Hydrogen is a key strategic component to fully decarbonizing the UK's economy and the UK is well positioned to lead on the production of green hydrogen with significant technical expertise in electrolysers from world leading companies such as ITM Power, and the potential to generate significant quantities of renewable energy from offshore wind [53]. Summing up in United Kingdom: 2017 (18 HRS, 93 FCEV; 2020 (13 HRS, 168 FCEV; 2025 (150 HRS, 10,000 FCEV); 2030 (1150 HRS, 1,600,000 FCEV).

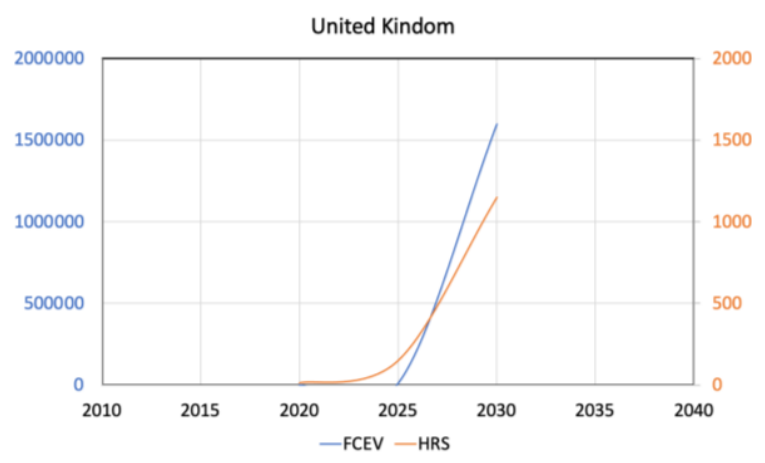

Fig. 7. The number of HRS and FCEVs in United Kindom (2017-2030)

\section{Hydrogenization of motor transport in Poland}

The territorial accessibility for hydrogen vehicles is determined by the availability of hydrogen refueling infrastructure, in the first place along with the TEN-T network $[9,55]$.

Within the European Project HIT-2-Corridors, as a result of the verification in Polish conditions, the original method developed for determining the initial location of the hydrogen refuelling station in Poland in the pre-commercial phase (2020-2030), the said location has been indicated along with the order of investment, taking into account above all the freedom to move around Poland of FC vehicles visiting Poland and transiting our country between other EU countries [9, 55].

The methodology developed is of a multi-stage character. Individual steps leading to the designation of the location of hydrogen refueling stations in Poland (as the methodology alone seems to be universal) are as follows:

Stage I: Method allowing to identify regions in which the hydrogen refueling stations should be located in the first place. The parameters considered include among others: 
average GDP per capita, average population density (habitants per $100 \mathrm{~km}^{2}$ ), the number of people living in the largest cities in the region, out of the cities with more 250 thousand inhabitants, average traffic volume of passenger cars on the national roads of international significance running through the region (passenger cars/24 hours).

Stage II: Method allowing to identify urban centres, in which should be located the said stations. The parameters considered include among others: average distance of the cities, over 250 thousand inhabitants, from the place of hydrogen manufacture (acquisition), average distance of the cities, over 250 thousand inhabit-ants from the nearest hydrogen refueling station located outside Poland, number of taxies in the city, number of municipal transport buses.

Stage III: Method for determining the area of the station location [9, 55]. The parameters considered are: results of locating the stations in question obtained in stage I and II, and relying on the results of the measurement of average traffic volume of passenger cars on the roads leading to these cities or on selected road junctions located near these cities, traffic flow intensity of passenger cars was included on the roads leading to the cities listed below.

With the above criteria, the order in the construction of HRS in Poland is as follows: 1 - Poznan, 2 - Warsaw, 3 Bialystok, 4 - Szczecin, 5 - the Lodz region, 6 - the TriCity region, 7 - Wroclaw, 8 - the Katowice region, 9 Krakow. The movement area of cars using fuel cells based on 9 base HRS (in total $30 \mathrm{HRS}$ ) situated in the national TEN-T road network by 2030 , will cover the territory of Poland. Full commercialization of the hydrogen technology in Poland according to the analyses and studies: the years 2040-2050 respectively: 200-600 HRS, Assumptions: 600 thousand - 2 million cars, 500--1000 buses, and 100-300 thousand cars transiting Poland annually $[9,55]$.

According to the e-mobility meter of the Polish Alternative Fuels Association (PSPA), the number of registrations of hydrogen passenger cars in Poland is 59; in the period January - August 2021, it was 58 units [56]. Polsat Group (Plus) alone has equipped itself with a fleet of hydrogen passenger cars (c.a. 50 passenger cars, including most likely 40 Toyota Mirai 2 and 10 Hyundai Nexo). A hydrogen refilling station was also established in Warsaw to supply them with hydrogen [57]. The hydrogen to power these cars will come from the Pątnów-Adamów-Konin Power Plant Complex (ZE PAK) belonging to the Polsat Group (Plus). This team decided to produce hydrogen using electricity obtained from biomass. It aims to produce hydrogen using electrolysers and use it to power buses. The first electrolyser will have a capacity of $2.5 \mathrm{MW}$, and together with the second, the capacity will increase to $5 \mathrm{MW}$. This gives 120 MWh of energy consumed per day to produce 2 tonnes of hydrogen or $60 \mathrm{kWh}$ of energy for every $\mathrm{kg}$ of hydrogen produced. One electrolyser will generate hydrogen for powering 50 buses per day, and two will power 100 buses per day [58].

The draft Polish Hydrogen Strategy to 2030 with a perspective until 2040 assumes that 100 to 250 new hydrogen buses will be put into operation from 2025. And from 2030, 800 to 1000 new hydrogen buses, including those manufactured in Poland. The said project also assumes the construc- tion of 32 new hydrogen refilling stations and the construction of at least five hydrogen valleys [59].

On May 18, 2021, a letter of intent was signed in Jesionka to create the Podkarpackie Hydrogen Valley [60]. During the Economic Forum in Karpacz this year, a letter of intent was signed regarding the creation of the Lower Silesian Hydrogen Valley [61]. In July this year, the creation of a hydrogen valley in Wielkopolska [62] was also announced. Planning to purchase buses are also Poznań (84 hydrogen buses) and Bielsko-Biała [63].

Hydrogen Eagle is an investment programme of the Orlen Group for the construction of an international network of hydrogen hubs (three in Poland, two in the Czech Republic, one in Slovakia) powered by electricity from renewable energy sources and innovative installations converting municipal waste into zero and low-emission hydrogen. Orlen wants to achieve a hydrogen generation capacity of approximately 50,000 tons per year by 2030 . In Włocławek, Trzebinia and Płock, automotive-quality hydrogen production installations are being built, with a target total production capacity of over $1000 \mathrm{~kg}$ per hour. The company has launched a tender procedure for the construction of HRS stations located in Poznań and Katowice. Electrolysis installations producing zero-emission hydrogen will be powered by offshore and onshore wind energy and photovoltaics, 54 hydrogen refueling stations for individual, public and freight transport will be built in Poland, and 22 facilities will be built in the Czech Republic and 26 in Slovakia [64]. Orlen will form the Mazovian Hydrogen Valley [65].

At the end of 2018, representatives of Lotos Group announced that the first two hydrogen refueling points would be built in Gdańsk and Warsaw. Both HRS are part of the Pure $\mathrm{H} 2$ project, of which $20 \%$ is paid for from EU funds, and the entire investment is expected to cost 10 million euros. The Pure $\mathrm{H} 2$ project will create three main installations: a hydrogen purification plant to the purity of 99.999 $\mathrm{H}_{2}$, hydrogen distribution plants, and two abovesaid refueling stations [66].

Last year, Lotos Group signed letters of intent regarding the supply of hydrogen and related refueling infra-structure for city buses with Gdynia, Wejherowo, Tczew and Rzeszów [67].

The most advanced project is Hydra Tank, comprising an experimental hydrogen refueling station. Polish Oil and Gas Company (PGNiG) has already signed a contract with a consortium of Polish- and UK-based companies to design and build the HRS. Slated for launch in 2021, the facility will be located at ul. Prądzyńskiego in the Wola District of Warsaw, in the vicinity of the existing CNG (compressed natural gas) filling station. PGNiG has start-ed investigating the possibility of storing and transmitting hydrogen using the natural gas network. A 'green hydrogen' production facility is to be built by the company's branch in Odolanów under the InGrid - Power to Gas project. It is scheduled to come on stream in 2022. PGNiG intends to use electricity generated by photovoltaic panels for the purpose of the project [67].

\section{Conclusions}

For the development of FCVs it is necessary, first of all, to develop the HRS infrastructure for refueling them. It 
happens so in Germany (ranking second in the number of HRS at the end of 2020 in the world), in France (ranking second in Europe), as well as in UK (third place in Europe) but also in other smaller countries of Northwestern Europe i.e. Denmark, the Netherlands or Belgium, but also in Norway, as set out in this article. All these countries have plans for the use of hydrogen, the development of hydrogen vehicle refueling infrastructure and the related development of the hydrogen vehicle fleet. In Northwest Europe, considering the countries mentioned above, are $158 \mathrm{HRS}$ in total at the end of 2020, i.e. about $83 \%$ HRS in Europe. In the above-mentioned countries of Northwestern Europe, there were also approx. $90 \%$ of FCEVs in Europe at the end of 2020. These countries dominate in the hydrogenisation of motor transport in Europe. There is only one HRS in Poland yet (during start-up) and 59 FCEV. Proposed locations of base HRS w Poland: 1 - Poznan, 2 - Warsaw, 3 - Bialystok, 4 - Szczecin, 5 - the Lodz region, 6 - the Tri-City region, 7 - Wroclaw, 8 - the Katowice region, 9 - Krakow, are justified, as indicated by the location plans in relation to HRS stations of the companies operating in the field of transport hydrogenisation.

The conducted analyses indicate that in aspect of the dynamics development of hydrogenisation of motor transport in Northwestern Europe, and in principle in Europe, Germany dominates. In Poland hydrogenisation of motor transport is only just developing. The most important thig is development of the refueling infrastructure for vehicles equipped with fuel cells. It should be developed first along the TEN-T road network running through Poland, as proposed in the article.

\section{Nomenclature}

CEP Clean Energy Partnership

$\mathrm{CO}_{2}$ Carbon dioxide

FCEV Fuel Cell Electric Vehicles

FCV Fuel Cell Vehicles

HDV Heavy-Duty Vehicles

HRS Hydrogen Refueling Stations
IEA International Energy Agency

LCV Light-Commercial Vehicles

MDV Medium-Duty Vehicles

MW Megawatts

PLDV Passenger Light-Duty Vehicle

\section{Bibliography}

[1] Delivering the European Green Deal. European Commission.

https://ec.europa.eu/info/strategy/priorities-20192024/european-green-deal/delivering-european-greendeal_en

[2] Communication from the Commission to the European Parliament, the Council, the European Economic and Social Committee and the Committee of the Regions. 'Fit for 55': delivering the EU's 2030 Climate Target on the way to climate neutrality. COM (2021) 550 final Brussels, 14.7.2021.

[3] Proposal for a Regulation of the European Parliament and the Council amending regulation (EU) 2019/631 as regards strengthening the $\mathrm{CO}_{2}$ emission performance standards for new passenger cars and new light commercial vehicles in line with the Union's increased climate ambition. COM (2021) 556 final, 2021/0197 (COD). Brussels, 14.7.2021.

[4] Communication from the Commission to the European Parliament, the Council, the European Economic and Social Committee and the Committee of the Regions. A hydrogen strategy for a climate-neutral Europe. COM (2020) 301 final. Brussels, 8.7.2020.

[5] Communication from the Commission to the European Parliament, the European Council, the European Economic and Social Committee and the Committee of the Regions. The European Green Deal. COM (2019) 640 final. Brussels, 11 December 2019.

[6] Communication from the Commission to the European Parliament, the European Council, the European Economic and Social Committee and the Committee of the Regions. Europe's moment: Repair and Prepare for the Next Generation. COM (2020) 456 final. Brussels, 27 May 2020.

[7] Europe's moment: Repair and prepare for the next generation. European Commission. https://ec.europa.eu

[8] Communication from the Commission to the European Parliament, the European Council, the European Economic and Social Committee and the Committee of the Regions.
Powering a climate - neutral economy: An EU Strategy for Energy System Integration. COM (2020) 299 final. Brussels. 8.7.2020.

[9] GIS, W., GIS, M. Overview of the method and state of hydrogenization of road transport in the world and the resulting development prospects in Poland. Open Engineering. 2021, 11(1), 570-583.

https://doi.org/10.1515/eng-2021-0039

[10] Hydrogen in North-Western Europe. A vision towards 2030. IEA, April 2021.

[11] SAMSUN, R.C., LAURENT, A., REX, M. et al. Deployment status of fuel cell in road transport: 2021 Update. Jülich Forschungszentrum, 2021.

[12] VAN DER LAAK, W., MARTENS, A., NEIS, S. National Implementation Plan Hydrogen Refuelling Infrastrukture Belgium - H2 Mobility Belgium, WaterstofNet, December 2015.

[13] VAN DER LAAK, W. H2 Mobility Belgium. A plan for the development of a hydrogen refuelling infrastructure and implementation of fuel cell electric vehicles in Belgium. www.hyer.eu/wp-content/uploads/2016/04/7-HydrogenRoad-Tour.pdf

[14] LEMKE, R. Market Introduction of Hydrogen Fuel, Berlin 2016.

[15] Wasserstoff - Spiegel, 1999, 1.

[16] Closer look at the deployment of fuel cell EVs as of Dec. 2017.

https://www.ieafuelcell.com/fileadmin/publications/AFC_T CP_survey_status_FCEV_2017.pdf.

[17] FRANÇOIS, I. National Policy Paper - Belgium. HyLAW Project, Dec. 2018.

[18] European Alternative Fuel Observatory, https://www.eafo/vehicles-and-fleet

[19] National Implementation Plan for Hydrogen Refueling Infrastructure, 3rd final edition, June 2014. 
[20] H2Mobilité France, Study for a Fuel Cell Electric Vehicle national deployment plan, Mobilité Hydrogéne France, 2017.

[21] Press Release, 12th Annual assessment of $\mathrm{H} 2$ stations by Ludwig-Bölkow-Systemtechnik (LBST), February 19, 2020.

[22] International Partnership for Hydrogen and Fuel Cells in Economy (IPHE), https://www.iphe.net

[23] Développons l'Hydrogéne pour l'économie française, Étude prospective, Associacion française pour l'hydrogéne et les piles á combustible (AFHYPAC), Paris 2018.

[24] Plan de déploiement de l'hydrogéne pour la transition énergétique, Rapport de Ministére de la Transition Écologique et Solidaire, Paris 2018.

[25] Wasserstoff - Spiegel, 1999, 2.

[26] Annual Report 2015 NOW GmbH.

[27] Annual Report 2018 NOW GmbH.

[28] BONHOF, K., THORSTEN, H., BUTSCH, H. 50 hydrogen refuelling stations in Germany. Within the frame of the National Innovation Programme Hydrogen and Fuel cell Technology, IFP/IEA/ITF Workshop, November 2012.

[29] BUTSCH, H. HRS Infrastructure in Germany and Europe Current Activities, Washington, June 2014.

[30] Bundesministerium für Verkehr und digitale Infrastruktur: Nationaler Strategierahmen über den Aufbau der Infrastruktur für alternative Kraftstoffe, November 2016.

[31] THORSTEN, H. Deployment of Hydrogen and Fuel Cell Technology in Germany, EHEC, Spain 2018 NOW GmbH.

[32] NITSCH, J. Was dedeutet ein Klima- und was bedeutet ein Energieziel für den Verkehrsector? Zweites Fach-gespräch in Rahmen des Fachdialogs zur Mobilitäts- und Kraftstoff strategie des BMVBS, Berlin, 17 Juli 2012.

[33] BONHOF, K. The renewable and Clean Hydrogen Challenge of Mission Innovation. Hydrogen Ministerial Meeting 23th October, 2018 Tokyo, Japan.

[34] Hydrogen scaling up, A sustainable pathway for the global energy transition, Hydrogen Council, November 2017.

[35] ROBINIUS, M., LINSSEN, J., GRUBE, T. et al. Comparative analysis of infrastructures: hydrogen fueling and electric charging of vehicles, Jürlich Forschungzentrum, Energie \& Umwelt/Energy\&Environment, Band/Volume 408.

[36] Press Release, 12th Annual assessment of H2stations.org by LBST, 19 February 2020.

[37] WEEDA, M. NIP - NL, Version June 2014. ECN 2014.

[38] WEEDA, M. Economic analysis of HRS network build-up in the Netherlands, Petten, 3 July 2015, ECN-E-15-067.

[39] WEEDA, M. New impetus for hydrogen in the Netherlands, Information Day, Hydrogen Innovation Mission to the Netherlands, Embassy of the Kingdom of the Netherlands, Tokyo, 30 May 2018.

[40] DENCHER, R. Demand gathering \& demand creation, Information Day, Hydrogen Innovation Mission to the Netherlands, Embassy of the Kingdom of the Netherlands, Tokyo, 30 May 2018.

[41] GIGLER, J., WEEDA, M. Outlines of a Hydrogen Roadmap. TKI NIEUW GAS, Topsector Energie, May 2018.

[42] VAN WIJK, A. et al. The Green Hydrogen Economy in the Northeern Netherlands, Groningen, the Netherlands October 2017.

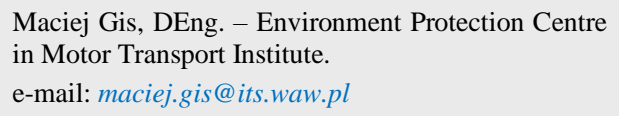

[43] Government Strategy on Hydrogen, Ministry of Economic Affairs and Climate policy, 06.04.2020.

[44] The Norwegian Government's hydrogen strategy towards a low emission society. Norwegian Ministry of Petroleum, Norwegian Ministry of Climate and Environment.

[45] The Norwegian hydrogen Guide, https://hydrogen.no

[46] HyNor- project, https://en.wikipedia.org/wiki/HyNor

[47] National Transport Plan 2018-2029. Norwegian Ministry of Transport and Communications.

[48] PÜTZ, K., NØRBECH, T. Background paper for the IFP/IEA/ITF Workshop on "Developing infrastructure for alternative transport fuels and powertrains to 2020/2030/ 2050: A cross country assessment of early stages of implementation" OECD, 30 November 2012.

[49] Action Plan 2012-2015. Recommendation by the Norwegian Hydrogen Council according to the mandate given by the Ministry of Petroleum and Energy and the Ministry of Transport and Communications.

[50] NTNU, IFE, SINTEF (2009) Recommendations to the Norwegian Government for the implementation of hydrogen as transportation fuel in Norway, available at http://www.ntnu.no/ept/norways

[51] UK H2 Mobility.Phase1Results. April 2013.

[52] HART, D., HOWES, J., MADDEN, B. et al. Hydrogen and Fuel Cells: Opportunities for Growth. A Roadmap for the UK. E4tech and Elementary Energy. November 2016.

[53] UK hydrogen strategy.GOV.UK, 17 August 2021, https://www.gov.uk/government/publications/uk-hydrogenstrategy

[54] Decarbonising Transport. A Better, Greener Britain. Department for Transport, 2021.

[55] GIS, W., MENES, E., WAŚKIEWICZ, J. et al. Circumstances of the national plan for hydrogenization of road transport in Poland. ITS, Warsaw 2015.

[56] Licznik elektromobilności: rozbudowa infrastruktury ładowania w Polsce nabiera tempa, https://pspa.com.pl

[57] KIFER, Ł. Pierwsza stacja tankowania wodoru jest gotowa i prywatna. Telewizja wyprzedziła spółki energetyczne. Jun. 2021, https://moto.pl

[58] Zespół Elektrowni Pątnów-Adamów-Konin będzie wytwarzał wodór z biomasy: $60 \mathrm{kWh}$ na $1 \mathrm{~kg}$ gazu. April 2020. https://elektrowoz.pl

[59] Polska Strategia Wodorowa do 2030 r. z perspektywą do 2040 r. - projekt, czerwiec 2021.

[60] Rzeszów sercem „Podkarpackiej Doliny Wodorowej”, 18.05.2021, https://www.gov.pl

[61] Premier: Dolnośląska Dolina Wodorowa przyczyni się do rozwoju naszej gospodarki, 9.9.2021, https://www.gov.pl

[62] WOŹNIAK, A. Śląsk wykorzysta wodór dla odchodzenia od węgla. Rzeczpospolita 23.8.2021.

[63] WOŹNIAK, A. UE dofinansuje zielony wodór w Polsce. Rzeczpospolita 23.8.2021, 29.7.2021.

[64] Grupa Orlen z międzynarodowym programem wodorowym, https://www.orlen.pl

[65] Orlen będzie tworzył Mazowiecką Dolinę Wodorową, 10.9.2021, https://www.bankier.pl

[66] Wodór na stacjach Lotosu od 2021, https://www.lotos.pl

[67] PGNiG launches new hydrogen programm, 12.5.2020, http://en.pgnig.pl

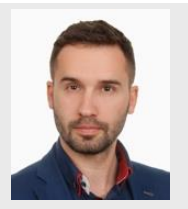

